\title{
Major ion chemistry and groundwater quality assessment for drinking and irrigation purpose in parts of Noyyal basin, Tamil Nadu, India
}

\author{
Karung Phaisonreng Kom ${ }^{1}$, B. Gurugnanam ${ }^{2}$ \\ ${ }^{1}$ Centre for Applied Geology, The Gandhigram Rural Institute-Deemed to be University, Dindigul, Tamil Nadu, \\ India. e-mail:phaikarung@gmail.com \\ ${ }^{2}$ Centre for Applied Geology, The Gandhigram Rural Institute-Deemed to be University, Dindigul, Tamil Nadu, \\ India. e-mail: gurugis4u@gmail.com
}

The present study was conducted to assess the groundwater quality for drinking and irrigation purposes in parts of Noyyal basin, Tamil Nadu, India based on several water quality indices. To investigate the groundwater quality in the present study, the water samples were collected from 25 borewells and analyzed for various physicochemical parameters such as $\mathrm{pH}$, EC (electrical conductivity), total dissolved solids (TDS), total hardness (TH), major cations $(\mathrm{Ca} 2+, \mathrm{Mg} 2+, \mathrm{Na}+, \mathrm{K}+)$ and anions (HCO3-, F-, Cl-, NO3-, and SO42-); standard methods were used to calculate the physicochemical parameters. The dominant cation and anion found in the groundwater were in the sequence of $\mathrm{Na}>\mathrm{Ca}>\mathrm{Mg}>\mathrm{K}$ and $\mathrm{HCO} 3>\mathrm{Cl}>\mathrm{SO} 42>\mathrm{NO} 3-$ $>$ F-, respectively. In some groundwater samples, parameters such as EC, total dissolved solids, total hardness, $\mathrm{Na}+, \mathrm{Ca} 2+, \mathrm{Mg} 2+, \mathrm{K}+, \mathrm{HCO} 3-, \mathrm{Cl}-$ exceed the standards of the World Health Organization (WHO) and Bureau of Indian Standards (BIS). However, the groundwater is suitable for drinking water with respect to $\mathrm{pH}$, SO42-, NO3-, F-. In terms of the irrigation purpose, various indices such as sodium absorption ratio (SAR), sodium percentage ( $\mathrm{Na} \%)$, soluble sodium percentage (SSP), residual sodium concentration (RSC), Kelley ratio (KR), and magnesium hazard (MH), and permeability Index (PI) were assessed to determine the water quality. From the computation, SAR values were found that $88 \%$ of groundwater samples fall in excellent class while $4 \%$ of samples fall in doubtful class. $\mathrm{Na} \%$ values indicate that $80 \%$ of samples are unsuitable for irrigation use. SSP values reveal that $84 \%$ of groundwater samples are in good categories whereas, $16 \%$ of samples are unsuitable. RSC values show that only $75 \%$ of samples are suitable for irrigation purpose, however, $8 \%$ of samples fall in a doubtful category and $20 \%$ are not suitable for irrigation purposes. KR values indicate $84 \%$ and $16 \%$ of groundwater samples are suitable and unsuitable, respectively. $\mathrm{MH}$ value shows that $100 \%$ of the samples are suitable for irrigation purposes. PI values indicate $32 \%, 52 \%$ and $16 \%$ of the samples fall within Class-I, Class-II, and Class-III, respectively. Yet the majority of groundwater samples are suitable for irrigation purpose, except some samples exceeds its suitability, this suggests that the groundwater quality of the study area can worsen in the near future. With increasing the used of fertilizers and pesticides in agricultural land and due to geogenic sources, it is necessary to conduct proper monitoring of the groundwater chemistry and the groundwater management plan is therefore required to improve the quality of the water in the study area. 